\title{
Metabolites of Hirsuteine and Hirsutine, the Major Indole Alkaloids of Uncaria rhynchophylla, in Rats
}

\author{
Takahiro Nakazawa, ${ }^{*}$ Koh-ichi BanBa, Kazumasa Hata, Yutaka Ninei, Ayumi HoshiKawa, and \\ Keisuke OHSAWA \\ Department of Natural Products Chemistry, Tohoku Pharmaceutical University; 4-4-1 Komatsushima, Aoba-ku, Sendai, \\ Miyagi 981-8558, Japan. Received January 20, 2006; accepted May 18, 2006; published online May 23, 2006
}

\begin{abstract}
The metabolic fate of hirsuteine (HT) and hirsutine (HS), the major indole alkaloids of Uncaria rhynchophylla, was investigated using rats. On HPLC analysis, urine from rats orally administered HT were found to contain two metabolites (HT1 and HT2) together with unchanged HT. Similarly HS also was metabolized to two compounds (HS1 and HS2). Metabolite structures were determined to be 11-hydroxyhirsuteine-11- $O$ - $\beta$-D-glucuronide (HT1), 11-hydroxyhirsuteine (HT2), 11-hydroxyhirsutine-11- $O$ - $\beta$-D-glucuronide (HS1) and 11-hydroxyhirsutine (HS2), based on spectroscopic and chemical data. HT1 and HS1 were also detected in bile from rats administered HT and HS, respectively. Total cumulative urinary excretion within $72 \mathrm{~h}$ of oral administration was approximately $14 \%$ and $26 \%$ of the HT and HS doses, respectively, while total cumulative biliary excretion was $35 \%$ and $46 \%$, respectively. HT and HS 11-hydroxylation were catalyzed by rat liver microsomes. This 11-hydroxylation activity was inhibited by addition of SKF-525A (a nonselective CYP inhibitor) or cimetidine (a CYP2C inhibitor). These results indicate that orally administered HT and HS are converted to 11-hydroxy metabolites in rats, and that the metabolites are predominantly excreted in bile rather than urine following glucuronidation. Furthermore, the results suggest that CYP2C enzymes are involved, at least in part, in the specific 11-hydroxylation of HT and HS.
\end{abstract}

Key words hirsuteine; hirsutine; metabolite; hydroxylation; Uncaria

The hooks of Uncaria rhynchophylla, $U$. sinensis and $U$. macrophylla are used in traditional Chinese herbal medicine as spasmolytic, analgesic and sedative treatments for many symptoms associated with hypertension and cerebrovascular disorders. ${ }^{1,2)}$ Many compounds have been isolated from these plants, including indole alkaloids, oxyindole alkaloids ${ }^{3,4)}$ and phenylpropanoids. ${ }^{5,6)}$ Hirsuteine (HT) and hirsutine (HS) are the major indole alkaloids of the Uncaria species and have been demonstrated to possess a central depressive and vasodilative effect ${ }^{7,8)}$ as well as a protective effect against neuronal death. ${ }^{9}$ ) However, no information is available on the metabolic fates of HT and HS in mammals. In most cases, traditional herbal medicines are prepared by extraction with hot water and are orally administered. The components present in the aqueous extract are thus metabolized by various enzymes and gut flora before being absorbed into the body. Accordingly, to evaluate the activity of herbal medicines, investigation regarding the metabolic fate of the constituents is very important.

It is well known that some metabolites, such as paeonimetabolin-I (a metabolite of paeoniflorin), are related to the pharmacological effects of herbal medicines. ${ }^{10)}$ We have demonstrated that the 5-hydroxy metabolite of 8-methoxypsolaren isolated from Angelica acutiloba is more effective than the parent compound against increased peripheral blood flow in mice. ${ }^{11)}$ Thus, it is common for metabolites of the constituents present in herbal medicines contribute to the pharmacological effects. The purpose of the present study, therefore, was to clarify the metabolic fates of HT and HS in mammals. We report here the chemical structures and cumulative excretion of urinary and biliary metabolites when HT and HS are orally administered to rats, as well as the contribution of hepatic microsome enzymes in this metabolism. This is the first study to clarify the chemical structures of HT and HS metabolites in animals.

\section{MATERIALS AND METHODS}

Apparatus Melting points were determined on a Yanagimoto micro melting point apparatus and are uncorrected. IR spectra were measured with a Perkin Elmer FT-IR1725X spectrometer. Optical rotations were in methanol or $\mathrm{H}_{2} \mathrm{O}$ using a Jasco DIP-360 digital polarimeter (cell length, $10 \mathrm{~mm}$ ). CD spectra were obtained with a JASCO ORD/CD $\mathrm{J}$-20 unit (cell length, $0.2 \mathrm{~mm}$ ). NMR spectra were recorded on a JEOL JNM-EX $400\left({ }^{1} \mathrm{H}, 400 ;{ }^{13} \mathrm{C}, 100 \mathrm{MHz}\right)$ spectrometer. Chemical shifts are given as $\delta$ values (ppm) downfield relative to tetramethylsilane. Electron impact MS (EI-MS) and FAB-MS were performed on a JEOL JMS-DX 303 mass spectrometer. The HPLC system comprised a CCPM pump, a CO-8010 column oven (Tosoh, Tokyo, Japan) and a model MCPD-3600 photodiode array detector (Otsuka, Osaka, Japan).

Reagents The hooks of Uncaria rhynchophylla were commercially obtained from Tsumura Co., Ltd. (Tokyo, Japan). $\beta$-Glucuronidase Type H-2 and SKF-525A were purchased from Sigma (St. Louis, MO, U.S.A.). Pooled male SD rat liver microsomes (Lot 14035) and NADPH-generating solution were from BD Gentest (Massachusetts, U.S.A.). Cimetidine was from Wako Pure Chemical Industries Ltd. (Osaka, Japan). HT and HS were isolated from MeOH extracts of Uncaria rhynchophylla by a combination of column chromatography with silica gel (EtOAc/MeOH) and preparative HPLC. Identities of all compounds were confirmed by MS, CD, ${ }^{1} \mathrm{H}$-, and ${ }^{13} \mathrm{C}-\mathrm{NMR}$ spectroscopy before use. ${ }^{12)}$ The purity of each compound was verified by HPLC (>98\%).

HPLC Conditions For qualitative and quantitative analysis, HPLC conditions were as follows: column, TSK gel ODS-120T (Tosoh, Tokyo, $250 \times 4.6 \mathrm{~mm}$ i.d., $5 \mu \mathrm{m}$ particle size); column temperature, $40{ }^{\circ} \mathrm{C}$; flow rate, $1.0 \mathrm{ml} / \mathrm{min}$; UV detection, $230 \mathrm{~nm}$. The mobile phase was a gradient system 
of $10 \mathrm{~mm}$ phosphate buffer solution $\mathrm{pH} 7.0$ (A) and $\mathrm{MeOH}$ (B). The gradient system for analysis was $\mathrm{A} / \mathrm{B}=90 / 10$ $(0 \mathrm{~min}) \rightarrow 10 / 90(50 \mathrm{~min}) \rightarrow 10 / 90(60 \mathrm{~min})$.

Animals Male Sprague-Dawley rats $(200-250 \mathrm{~g})$ were purchased from Japan SLC Inc. Animals were housed in a temperature- $\left(22 \pm 2^{\circ} \mathrm{C}\right)$, humidity- $(55 \pm 10 \%)$, and light(8:00-20:00) controlled room with free access to distilled water and commercial rodent chow (CE-2, Clea Japan Inc., Tokyo, Japan).

Drug Administration After $7 \mathrm{~d}$ of feeding, food was withheld for $18 \mathrm{~h}$, after which a solution of HT or HS $(50 \mathrm{mg} / \mathrm{kg})$ in propylene glycol was orally administered by direct stomach intubation at a constant volume of $1 \mathrm{ml} / \mathrm{kg}$ body weight. Animals were allowed free access to water and sugar during the experiments. Experimental procedures were conducted in accordance with the protocols approved by the Committee of Animal Experiments of Tohoku Pharmaceutical University.

Urine Samples Urine samples were collected for $72 \mathrm{~h}$ at 24-h intervals after oral administration of HT and HS (50 $\mathrm{mg} / \mathrm{kg}$ ) using a metabolic cage. Each urine sample was filtered through a $0.45-\mu \mathrm{m}$-membrane filter, and $20 \mu \mathrm{l}$ of the sample was subjected to HPLC.

Bile Sample After rats were anesthetized by intraperitoneal injection of sodium pentobarbital $(20 \mathrm{mg} / \mathrm{kg})$, the bile duct was exposed and a small incision was made in the duct wall with microspring scissors. A catheter, fashioned from a $500-\mathrm{mm}$ segment of polyethylene tube (ID $0.50 \mathrm{~mm}$, OD $1.00 \mathrm{~mm}$, Kunii) welded to a $40-\mathrm{mm}$ polyethylene segment (ID $0.28 \mathrm{~mm}$, OD $0.61 \mathrm{~mm}$, Becton), was introduced through the incision and advanced $10 \mathrm{~mm}$. After the catheter was tunneled to exit via a small hole in the skin on the dorsal side of the neck, the abdominal incision was closed using sutures and wound clipping. The exteriorized catheter was connected to a cannula swivel (model TCS2-21, Tsumura; Tokyo, Japan), and the rats were placed in a plastic cage with a freemoving system (Tsumura) that rotated through $360^{\circ}$ in the horizontal plane and through $180^{\circ}$ in the vertical plane, thus giving the animals freedom of movement. One hour after preparation, HT and HS $(50 \mathrm{mg} / \mathrm{kg})$ were orally administered. Bile samples were collected in tubes chilled with ice water for $72 \mathrm{~h}$ at 24 -h intervals. Samples $(20 \mu \mathrm{l})$ were filtered through a $0.45-\mu \mathrm{m}$-filter membrane and subjected to HPLC.

Enzymatic Hydrolysis of Urine Sample Urine samples were transferred to test tubes containing $5.0 \mathrm{ml}$ of $0.2 \mathrm{M}$ sodium acetate buffer (pH 5.5) and $50 \mu$ of $\beta$-glucuronidase solution, and were incubated at $37^{\circ} \mathrm{C}$ for $24 \mathrm{~h}$. The incubated solution was extracted three times with ethyl acetate $(20 \mathrm{ml})$. The organic layer was then evaporated to dryness at $40^{\circ} \mathrm{C}$. The residue was dissolved in $1.0 \mathrm{ml}$ of methanol and a $20-\mu 1$ aliquot was subjected to HPLC.

Isolation of Urinary and Biliary Metabolites For urinary and biliary metabolite isolation, total administration of HT and HS were as follows: urine samples, HT $280 \mathrm{mg}$ and HS $285 \mathrm{mg}$; bile samples, HT $84 \mathrm{mg}$ and HS $82 \mathrm{mg}$. Urine $(400 \mathrm{ml})$ and bile $(100 \mathrm{ml})$ obtained from 20 and 6 rats, respectively, was successively subjected to Sephadex LH-20 with $\mathrm{MeOH}$, and fractions containing metabolites were evaporated to dryness under reduced pressure at $40{ }^{\circ} \mathrm{C}$. The residue was dissolved in a small amount of methanol and was further purified by preparative HPLC under the following conditions: column, TSKgel ODS-120T $(300 \times 7.8 \mathrm{~mm}$ i.d., $5 \mu \mathrm{m}$ particle size, Tosoh Company Ltd., Tokyo, Japan); mobile phase, $\mathrm{H}_{2} \mathrm{O}$ (solvent $\mathrm{A}$ ) and methanol (solvent $\mathrm{B}$ ), linear gradient system, $A / B=90 / 10(0 \mathrm{~min}) \rightarrow 10 / 90(50 \mathrm{~min})$. Flow rate was $2.0 \mathrm{ml} / \mathrm{min}$ at room temperature. Each metabolite fraction was evaporated to dryness at $40^{\circ} \mathrm{C}$ in vacuo to afford HT1 (10 mg), HT2 (5 mg), HT3 (5 mg), HT4 (5 mg), HS1 (15 mg), HS2 (5 mg) HS3 (3 mg) and HS4 (10 mg). These compounds (HT1-3 and HS1-3) were used as authentic samples for the quantitative and qualitative analysis of metabolites.

Incubation of HT and HS with Rat Liver Microsomes The standard incubation mixture consisted of rat liver microsomes $(0.2-3.0 \mathrm{mg}$ protein $/ \mathrm{ml})$, and $100 \mu \mathrm{M}$ HT and HS (dissolved in DMSO) in a final volume of $1.0 \mathrm{ml}$ of $100 \mathrm{~mm}$ PBS $(\mathrm{pH} 7.4)$ containing an NADPH-generating system $\left(0.67 \mathrm{mg} / \mathrm{ml} \mathrm{MgCl}_{2}, 0.5 \mathrm{~mm} \mathrm{NADP}{ }^{+}, 5 \mathrm{~mm}\right.$ glucose 6-phosphate, and 0.5 units of glucose 6-phosphate dehydrogenase/ $\mathrm{ml}$ ). Incubation was carried out at $37^{\circ} \mathrm{C}$ for $1 \mathrm{~h}$ in a test tube and was terminated by adding $100 \mu \mathrm{l}$ of acetonitrile and cooling on ice. The mixture was vortexed for $1 \mathrm{~min}$ and was then centrifuged at $10000 \times \boldsymbol{g}$ for $10 \mathrm{~min}$. Reaction supernatant was filtered through a $0.45-\mu \mathrm{m}$ membrane filter, and $20 \mu \mathrm{l}$ was then subjected to HPLC. SKF-525A and cimetidine $(62.5-500 \mu \mathrm{M})$ were dissolved in DMSO such that the final concentration of the vehicle in the incubation mixture was $1.0 \%$. Inhibitors were added to incubation mixtures $(0.5 \mathrm{mg}$ protein $/ \mathrm{ml})$ containing the NADPH-generating system $15 \mathrm{~min}$ before addition of substrates at $25 \mu \mathrm{M}$, and activity was compared to that in identical incubation mixtures without inhibitor. The concentrations of chemical CYP inhibitors were selected according to the methods of previous reports. ${ }^{13-16)}$ These incubations were performed in triplicate.

Calibration Curves Calibration curves were prepared by spiking predose urine, bile and PBS with known amounts of metabolites in a final concentration range of $12.20 \times 10^{-1}$ $\mu \mathrm{g} / \mathrm{ml}-12.2 \times 10 \mu \mathrm{g} / \mathrm{ml}$ (in urine and bile samples) or $11.75 \times 10^{-2} \mu \mathrm{g} / \mathrm{ml}-58.75 \times 10^{-1} \mu \mathrm{g} / \mathrm{ml}$ (in incubation solutions). Metabolite concentrations were determined from the peak area using the equation for linear regression obtained from the calibration curves.

Recovery Known amounts of metabolites $(0.51-0.10$ $\mathrm{mg})$ were added to blank urine $(20 \mathrm{ml})$, bile $(10 \mathrm{ml})$ and PBS $(100 \mathrm{ml})$, and were subjected to determination. Recoveries were calculated by comparing experimental values with corresponding theoretical values. Metabolite recoveries from rat urine bile, and PBS were found to be $90.7-95.5 \%$.

HT1 Amorphous powder, mp $195^{\circ} \mathrm{C}$ (dec.). $[\alpha]_{\mathrm{D}}^{22}$ $+18.0^{\circ}(c=1.0, \mathrm{MeOH})$. IR $(\mathrm{KBr}) v_{\max } 3410(\mathrm{NH}), 1697$ $(\mathrm{C}=\mathrm{O}), 1633(\mathrm{C}=\mathrm{C}) \mathrm{cm}^{-1}, \mathrm{CD}(c=0.2, \mathrm{MeOH}) \mathrm{nm}(\Delta \varepsilon \lambda)$ $232(-9.9), 238(0), 245(+7.6), 266(0), 275(-1.1), 285$ $(-1.2), 297(-2.6), 315(0) .{ }^{1} \mathrm{H}-\mathrm{NMR}$ (DMSO- $\left.d_{6}\right) \delta: 2.18$ $(1 \mathrm{H}, \mathrm{d}, J=12.0 \mathrm{~Hz}, \mathrm{H}-14), 2.30(1 \mathrm{H}, \mathrm{m}, \mathrm{H}-15), 2.38(1 \mathrm{H}, \mathrm{m}$, H-6), $2.57(2 \mathrm{H}$, br d, $J=16.8 \mathrm{~Hz}, \mathrm{H}-21), 2.80(1 \mathrm{H}, \mathrm{m}, \mathrm{H}-20)$, $2.83(1 \mathrm{H}, \mathrm{m}, \mathrm{H}-6), 3.07(1 \mathrm{H}, \mathrm{m}, \mathrm{H}-5), 3.12(1 \mathrm{H}, \mathrm{m}, \mathrm{H}-5)$, $3.33\left(1 \mathrm{H}, \mathrm{m}, \mathrm{H}-3^{\prime}\right), 3.38\left(1 \mathrm{H}, \mathrm{m}, \mathrm{H}-2^{\prime}\right), 3.41\left(1 \mathrm{H}, \mathrm{m}, \mathrm{H}-4^{\prime}\right)$, $3.59\left(3 \mathrm{H}, \mathrm{s}, \mathrm{COOC}_{3}\right), 3.70\left(1 \mathrm{H}, \mathrm{d}, J=9.3 \mathrm{~Hz}, \mathrm{H}-5^{\prime}\right), 3.77$ $\left(3 \mathrm{H}, \mathrm{s}, \mathrm{OC}_{3}\right), 4.35(1 \mathrm{H}, \mathrm{br} \mathrm{s}, \mathrm{H}-3), 4.84(2 \mathrm{H}, \mathrm{m}, \mathrm{H}-18), 4.88$ $\left(1 \mathrm{H}, \mathrm{d}, J=7.3 \mathrm{~Hz}, \mathrm{H}-1^{\prime}\right), 5.34(1 \mathrm{H}, \mathrm{m}, \mathrm{H}-19), 6.71(1 \mathrm{H}, \mathrm{dd}$, $J=2.0,8.5 \mathrm{~Hz}, \mathrm{H}-10), 6.99(1 \mathrm{H}, \mathrm{d}, J=2.0 \mathrm{~Hz}, \mathrm{H}-12), 7.24$ $(1 \mathrm{H}, \mathrm{d}, J=8.5 \mathrm{~Hz}, \mathrm{H}-9), 7.36(1 \mathrm{H}, \mathrm{s}, \mathrm{H}-17), 10.67(1 \mathrm{H}, \mathrm{s}$, 
NH). ${ }^{13} \mathrm{C}-\mathrm{NMR}$ (DMSO- $\left.d_{6}\right) \delta: 16.2$ (C-6), 29.4 (C-14), 32.9

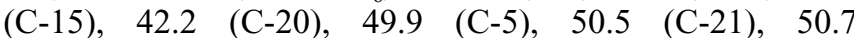
$\left(\mathrm{COOCH}_{3}\right), 53.5(\mathrm{C}-3), 61.4\left(\mathrm{OCH}_{3}\right), 71.4\left(\mathrm{C}-4^{\prime}\right), 73.1(\mathrm{C}-$ $\left.2^{\prime}\right), 75.1\left(\mathrm{C}-5^{\prime}\right), 75.9\left(\mathrm{C}-3^{\prime}\right), 98.7$ (C-12), $101.6\left(\mathrm{C}-1^{\prime}\right), 105.6$ (C-7), 109.9 (C-10), 110.5 (C-16), 115.1 (C-18), 117.5 (C-9), 122.7 (C-8), 132.2 (C-2), 136.0 (C-13), 139.4 (C-19), 152.7 (C-11), 160.1 (C-17), $167.4\left(\mathrm{COOCH}_{3}\right), 171.5$ (C-6'). Negative-ion FAB-MS m/z: $579[\mathrm{M}-2 \mathrm{H}+\mathrm{Na}]^{-}, 557[\mathrm{M}-\mathrm{H}]^{-}$, $381[\mathrm{M}-\mathrm{H}-\mathrm{GlcUA}]^{-}$. Negative-ion HR-FAB-MS $\mathrm{m} / \mathrm{z}$ : 557.2125, Calcd for $\mathrm{C}_{28} \mathrm{H}_{33} \mathrm{~N}_{2} \mathrm{O}_{10}, 557.2136$.

HT2 Brown powder, mp $127^{\circ} \mathrm{C}$ (dec.). $[\alpha]_{\mathrm{D}}^{20}+97.7^{\circ}$ $(c=1.1, \mathrm{MeOH})$. IR $(\mathrm{KBr}) v_{\max } 3406(\mathrm{NH}), 1702(\mathrm{C}=\mathrm{O})$, $1633(\mathrm{C}=\mathrm{C}) \mathrm{cm}^{-1}$. CD $(c=0.2, \mathrm{MeOH}) \mathrm{nm}(\Delta \varepsilon \lambda) 228$ $(+0.4), 247$ (6.5), $266(0), 276(-1.2), 303(-1.8), 324(0)$. ${ }^{1} \mathrm{H}-\mathrm{NMR}\left(\mathrm{CDCl}_{3}\right) \delta: 2.00(1 \mathrm{H}, \mathrm{m}, \mathrm{H}-14), 2.35(2 \mathrm{H}, \mathrm{m}, \mathrm{H}-$ 15), 2.41 (1H, m, H-14), 2.53 (1H, m, H-6), 2.66 (2H, m, H21), 2.97 (1H, m, H-6), 3.01 (1H, m, H-20), 3.27 (1H, m, H5), $3.68\left(3 \mathrm{H}, \mathrm{s}, \mathrm{COOC}_{3}\right), 3.75\left(3 \mathrm{H}, \mathrm{s}, \mathrm{OCH}_{3}\right), 4.55(1 \mathrm{H}$, br s, H-3), 4.85 (1H, dd. $J=2.0,10.3 \mathrm{~Hz}, \mathrm{H}-18), 4.92(1 \mathrm{H}$, dd, $J=2.0,17.4 \mathrm{~Hz}, \mathrm{H}-18), 5.36(1 \mathrm{H}, \mathrm{m}, \mathrm{H}-19), 6.69(1 \mathrm{H}, \mathrm{dd}$, $J=2.0,8.3 \mathrm{~Hz}, \mathrm{H}-10), 6.87$ (1H, d, $J=2.0 \mathrm{~Hz}, \mathrm{H}-12), 7.26$ (1H, s, H-17), 7.31 (1H, d, J=8.3 Hz, H-9), $7.90(1 \mathrm{H}, \mathrm{s}, \mathrm{NH})$. ${ }^{13} \mathrm{C}-\mathrm{NMR}\left(\mathrm{CDCl}_{3}\right) \delta$ : $17.0(\mathrm{C}-6), 31.1(\mathrm{C}-14), 34.1(\mathrm{C}-15)$, 42.9 (C-20), 51.1 (C-5), $51.2(\mathrm{C}-21), 51.3\left(\mathrm{COOCH}_{3}\right), 54.0$ (C-3), $61.5\left(\mathrm{OCH}_{3}\right), 97.5$ (C-12), 107.7 (C-7), 109.1 (C-10), 111.7 (C-16), 115.3 (C-18), 118.4 (C-9), 122.4 (C-8), 131.6 (C-2), 136.8 (C-13), 139.5 (C-19), 151.9 (C-11), 159.7 (C17), $168.9\left(\mathrm{COOCH}_{3}\right)$. HR-EI-MS m/z: 382.1876, Calcd for $\mathrm{C}_{22} \mathrm{H}_{26} \mathrm{~N}_{2} \mathrm{O}_{4}, 382.1892$.

HS1 Amorphous powder, mp $198-200^{\circ} \mathrm{C}$. $[\alpha]_{\mathrm{D}}^{25}+5.0^{\circ}$ $\left(c=1.0, \mathrm{H}_{2} \mathrm{O}\right)$. IR $(\mathrm{KBr}) v_{\max } 3421(\mathrm{NH}), 1692(\mathrm{C}=\mathrm{O}), 1632$ $(\mathrm{C}=\mathrm{C}) \mathrm{cm}^{-1}$. $\mathrm{CD}(c=0.2, \mathrm{MeOH}) \mathrm{nm}(\Delta \varepsilon \lambda) 232(-9.9)$, 238 (0), 245 (+7.6), 266 (0), $275(-1.1), 285$ (-1.2), 297 $(-2.6), 315(0) .{ }^{1} \mathrm{H}-\mathrm{NMR}$ (DMSO-d $) \delta: 0.70(3 \mathrm{H}, \mathrm{t}, J=7.1$ Hz, H-18), 0.78 (1H, m, H-19), 1.21 (1H, m, H-19), 2.06 (1H, m, H-20), 2.10 (1H, m, H-14), 2.19 (1H, m, H-15), 2.40 (1H, m, H-5), 2.45 (1H, m, H-14), 2.50 (1H, m, H-6), 2.85 (1H, m, H-5), 2.87 (1H, m, H-6), 3.13 (1H, m, H-21), 3.25 $\left(1 \mathrm{H}, \mathrm{m}, \mathrm{H}-2^{\prime}\right), 3.28$ (1H, m, H-3'), 3.29 (1H, m, H-4'), 3.30 $(1 \mathrm{H}, \mathrm{m}, \mathrm{H}-21), 3.60\left(3 \mathrm{H}, \mathrm{s}, \mathrm{COOCH}_{3}\right), 3.70(1 \mathrm{H}, \mathrm{d}, J=9.3$

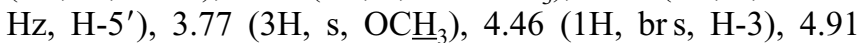
$\left(1 \mathrm{H}, \mathrm{d}, J=7.3 \mathrm{~Hz}, \mathrm{H}-1^{\prime}\right), 6.72(1 \mathrm{H}, \mathrm{dd}, J=2.2,8.5 \mathrm{~Hz}, \mathrm{H}-10)$, $6.99(1 \mathrm{H}, \mathrm{d}, J=2.2 \mathrm{~Hz}, \mathrm{H}-12), 7.23(1 \mathrm{H}, \mathrm{d}, J=8.5 \mathrm{~Hz}, \mathrm{H}-9)$, 7.42 (1H, s, H-17), 10.73 (1H, s, NH). ${ }^{13} \mathrm{C}-\mathrm{NMR}$ (DMSO-d $)$ $\delta: 10.9$ (C-18), 16.0 (C-6), 23.6 (C-19), 29.6 (C-14), 33.2 $(\mathrm{C}-15), \quad 37.6 \quad(\mathrm{C}-20), \quad 49.9 \quad(\mathrm{C}-5), \quad 50.4 \quad(\mathrm{C}-21), \quad 50.8$ $\left(\mathrm{COOC} \mathrm{CH}_{3}\right), 53.7(\mathrm{C}-3), 61.4\left(\mathrm{OCL}_{3}\right), 71.6\left(\mathrm{C}-4^{\prime}\right), 73.1(\mathrm{C}-$ $\left.2^{\prime}\right), 74.9$ (C-5'), $76.0\left(\mathrm{C}-3^{\prime}\right), 98.6$ (C-12), $101.3\left(\mathrm{C}-1^{\prime}\right), 105.2$ (C-7), 109.8 (C-10), 110.1 (C-16), 117.6 (C-9), 122.4 (C-8), 131.7 (C-2), 136.2 (C-13), 152.8 (C-11), 160.4 (C-17), 167.4 $\left(\mathrm{COOCH}_{3}\right), 171.0\left(\mathrm{C}-6^{\prime}\right)$. Negative-ion FAB-MS $m / z: 581$ $[\mathrm{M}-2 \mathrm{H}+\mathrm{Na}]^{-}, 559[\mathrm{M}-\mathrm{H}]^{-}, 383[\mathrm{M}-\mathrm{H}-\mathrm{GlcUA}]^{-}$. Negative-ion HR-FAB-MS $m / z$ : 559.2282, Calcd for $\mathrm{C}_{28} \mathrm{H}_{35} \mathrm{~N}_{2} \mathrm{O}_{10}$, 559.2292 .

HS2 Brown amorphous powder, $\mathrm{mp} 150-152^{\circ} \mathrm{C}$ (dec.). $[\alpha]_{\mathrm{D}}^{20}+97.7^{\circ}(c=1.0, \mathrm{MeOH}) . \mathrm{IR}(\mathrm{KBr}) v_{\max } 3407(\mathrm{NH})$, $1698(\mathrm{C}=\mathrm{O}), 1632(\mathrm{C}=\mathrm{C}) \mathrm{cm}^{-1} . \mathrm{CD}(c=0.2, \mathrm{MeOH}) \mathrm{nm}$ $(\Delta \varepsilon \lambda) 228(+0.4), 247(6.5), 266(0), 276(-1.2), 303$ $(-1.8), 324(0) .{ }^{1} \mathrm{H}-\mathrm{NMR}\left(\mathrm{CDCl}_{3}\right) \delta: 0.76(3 \mathrm{H}, \mathrm{m}, \mathrm{H}-18)$, $0.85(1 \mathrm{H}, \mathrm{m}, \mathrm{H}-19), 1.27(1 \mathrm{H}, \mathrm{m}, \mathrm{H}-19), 1.95(1 \mathrm{H}, \mathrm{brd}$, $J=13.4 \mathrm{~Hz}, \mathrm{H}-14), 2.17$ (1H, m, H-20), 2.36 (1H, m, H-15),
2.48 (1H, m, H-21), 2.53 (1H, m, H-14), 2.59 (1H, m, H-6), 2.79 (1H, m, H-21), 2.98 (1H, m, H-6), 3.28 (2H, m, H-5), $3.67\left(3 \mathrm{H}, \mathrm{s}, \mathrm{COOCH}_{3}\right), 3.73\left(3 \mathrm{H}, \mathrm{s}, \mathrm{OCH}_{3}\right), 4.42(1 \mathrm{H}, \mathrm{br}$, $\mathrm{H}-3), 6.69$ (1H, dd, $J=1.5,8.3 \mathrm{~Hz}, \mathrm{H}-10), 6.86(1 \mathrm{H}, \mathrm{d}, J=1.5$ Hz, H-12), 7.29 (1H, d, J=8.3 Hz, H-9), 7.31 (1H, s, H-17), $7.95(1 \mathrm{H}, \mathrm{s}, \mathrm{NH}) .{ }^{13} \mathrm{C}-\mathrm{NMR}\left(\mathrm{CDCl}_{3}\right) \delta: 1.3(\mathrm{C}-18), 17.0(\mathrm{C}-$ 6), 24.3 (C-19), 31.7 (C-14), 34.8 (C-15), 38.9 (C-20), 50.6 $(\mathrm{C}-21), 50.8$ (C-5), $51.3\left(\mathrm{COOCH}_{3}\right), 54.1$ (C-3), 61.5 $\left(\mathrm{OCH}_{3}\right), 97.6(\mathrm{C}-12), 107.5$ (C-7), 109.2 (C-10), $111.8(\mathrm{C}-$ 16), 118.3 (C-9), 122.2 (C-8), 131.7 (C-2), 136.9 (C-13), 152.1 (C-11), 159.8 (C-17), $169.1\left(\mathrm{COOCH}_{3}\right)$. HR-EI-MS $m / z: 384.2039$, Calcd for $\mathrm{C}_{22} \mathrm{H}_{28} \mathrm{~N}_{2} \mathrm{O}_{4}, 384.2040$.

\section{RESULTS}

Identification of Metabolites For preliminary detection of HT and HS metabolites in rat urine and bile, HPLC fingerprint profiles of these metabolites were developed using a photodiode array detector. With phosphate buffer solution (pH 7.0) and methanol solvent, three metabolites were detected in urine samples after oral administration of HT and $\mathrm{HS}$ at $50 \mathrm{mg} / \mathrm{kg}$ (HT1-3 and $\mathrm{HS} 1-3$, respectively), as shown in Fig. 1. The retention times for the metabolites were as follows: HT1 $-26 \mathrm{~min}$, HT2 $-36 \mathrm{~min}$, HT3 $-44 \mathrm{~min}$, HS1 $-28 \mathrm{~min}$, HS2 $-38 \mathrm{~min}$, and HS3 $-46 \mathrm{~min}$. On the other hand, analysis of the bile samples revealed the presence of a single metabolite for each compound (HT4 -26 min and HS4 $-28 \mathrm{~min})$. Representative chromatograms of the bile samples are shown in Fig. 2.

The IR spectra of all metabolites exhibited absorption due

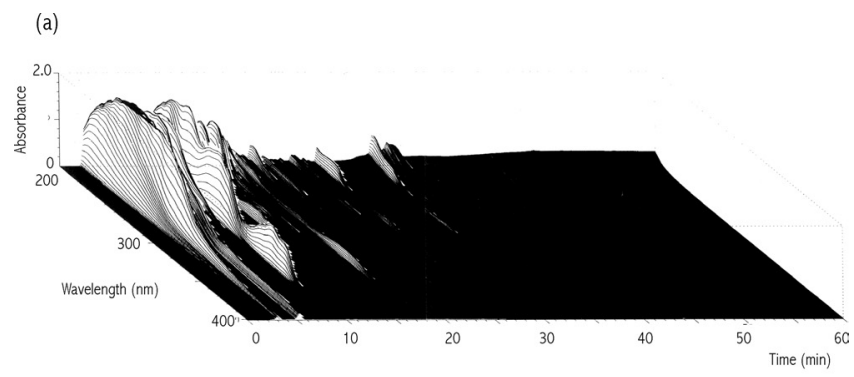

(b)

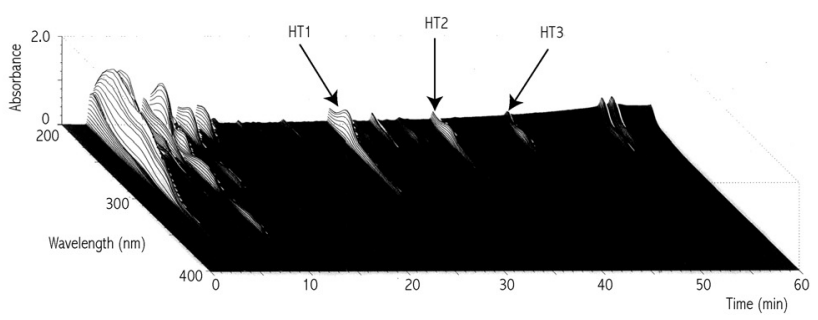

(c)

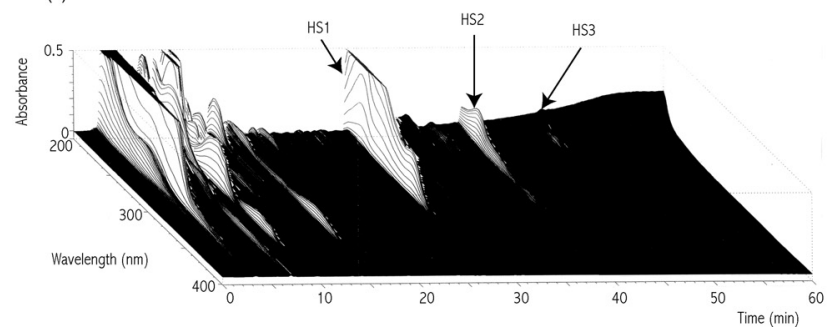

Fig. 1. HPLC Chromatograms of Urine Samples Following Oral Administration of Vehicle (a), HT (b) and HS (c) $(50 \mathrm{mg} / \mathrm{kg})$ to Rats 

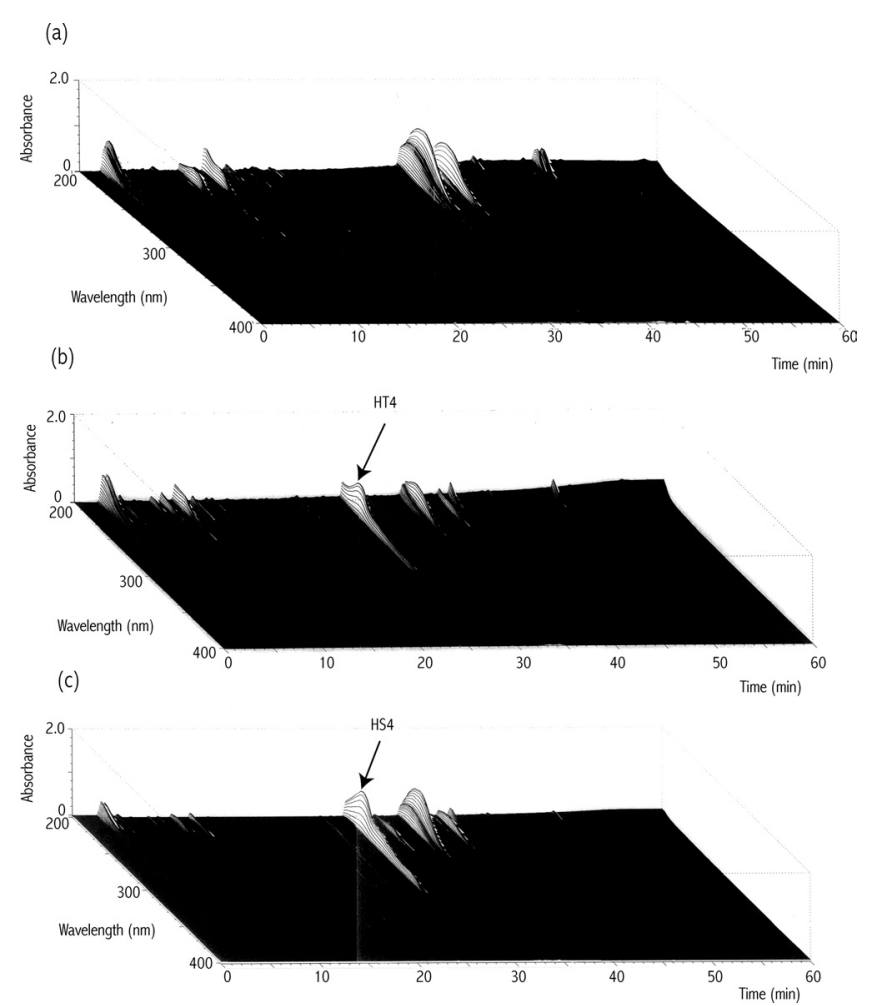

Fig. 2. HPLC Chromatograms of Bile Samples Following Oral Administration of Vehicle (a), HT (b) and HS (c) $(50 \mathrm{mg} / \mathrm{kg})$ to Rats

to NH $\left(3406-3421 \mathrm{~cm}^{-1}\right)$ and ester carbonyl groups $\left(1692-1702 \mathrm{~cm}^{-1}\right)$, but Wenkert-Bohlmann bands $(2700$ $2800 \mathrm{~cm}^{-1}$ ) were not observed. On the CD spectra, a negative Cotton effect in the longer wavelength region between 266 $324 \mathrm{~nm}$ was observed. ${ }^{1} \mathrm{H}$ - and ${ }^{13} \mathrm{C}-\mathrm{NMR}$ spectra also suggested that all metabolites were Corynanthe-type indole alkaloids with the pseudo configuration $(\mathrm{C} 3 \mathrm{H} \beta, \mathrm{C} 15 \mathrm{H} \alpha$, $\mathrm{C} 20 \mathrm{H} \beta$ ), similar to the parent compounds. ${ }^{17)}$

Metabolite HT2 was obtained as a pale yellow amorphous powder, $[\alpha]+95.0^{\circ}$. High-resolution EIMS analysis gave an $\mathrm{m} / \mathrm{z}$ of $382.1876[\mathrm{M}]^{+}(\Delta-1.6 \mathrm{mmu})$ and established the molecular formula as $\mathrm{C}_{22} \mathrm{H}_{26} \mathrm{~N}_{2} \mathrm{O}_{4}$. The NMR spectrum of HT2 was similar to the parent compound, HT, except for the aromatic region. A difference of 16 mass units in the mass spectrum relative to HT $\left(\mathrm{m} / \mathrm{z} 366[\mathrm{M}]^{+}\right)$indicated the presence of an additional hydroxyl group in HT2. On the ${ }^{1} \mathrm{H}-\mathrm{NMR}$ spectrum, the signals in the aromatic region showed an ABC-type signal at $\delta 6.69[1 \mathrm{H}, \mathrm{dd}, J=2.0,8.3 \mathrm{~Hz}], 6.87[1 \mathrm{H}, \mathrm{d}, J=2.0$ $\mathrm{Hz}]$ and $7.31[1 \mathrm{H}, \mathrm{d}, J=8.3 \mathrm{~Hz}]$. Furthermore, a comparison of the ${ }^{13} \mathrm{C}-\mathrm{NMR}$ spectrum of HT2 with HT showed that the C-11 signal shifted upfield by $30.8 \mathrm{ppm}$, accompanied by downfield shifts of C-10 (13.5 ppm) and C-12 (6.0 ppm). Accordingly, a substitution at position 11 was assumed. The tentative structure was further supported by $\mathrm{C}-\mathrm{H}$ COSY and ${ }^{1} \mathrm{H}$-detected heteronuclear multiple bond correlation (HMBC) experiments, and HT2 was concluded to be 11-hydroxyhirsuteine.

Metabolite HS2 was obtained as a pale yellow amorphous powder, $[\alpha]+97.7^{\circ}$. High-resolution EI-MS analysis gave an $\mathrm{m} / \mathrm{z}$ of $384.2039[\mathrm{M}]^{+}(\delta-1.0 \mathrm{mmu})$ and established the molecular formula as $\mathrm{C}_{22} \mathrm{H}_{28} \mathrm{~N}_{2} \mathrm{O}_{10}$. The molecular ion peak $(\mathrm{m} / \mathrm{z}$ $384,[\mathrm{M}]^{+}$) on EI-MS was 16 mass units higher than its par- ent compound, HS. This difference can be attributed to the hydroxy group in the aromatic ring, as was the case with metabolite HT2, thus suggesting that an oxygen was added to HS. Most of the signals on the NMR spectra were similar to those of HS. However, the signals for the aromatic region on ${ }^{1} \mathrm{H}-\mathrm{NMR}$ showed an ABC-type at $\delta 6.69[1 \mathrm{H}, \mathrm{dd}, J=1.5,8.3$ $\mathrm{Hz}$ ], 6.86 [1H, d, $J=1.5 \mathrm{~Hz}]$ and $7.29[1 \mathrm{H}, \mathrm{d}, J=8.3 \mathrm{~Hz}]$. Comparison of the ${ }^{13} \mathrm{C}-\mathrm{NMR}$ spectra of $\mathrm{HS} 2$ and $\mathrm{HS}$ indicated that the C-11 signal of HS2 shifted upfield by 30.4 ppm, accompanied by downfield shifts of C-10 (10.3 ppm) and $-12(13.8 \mathrm{ppm})$, indicating that the hydroxy group is situated at $\mathrm{C}-11$. This tentative structure was supported by 2DNMR spectra (C-H COSY, HMBC). Thus, HS2 was determined to be 11-hydroxyhirsutine.

Metabolite HT1 was obtained as an amorphous powder, $[\alpha]+18.0^{\circ}$. FAB-MS showed a pseudomolecular ion peak at $\mathrm{m} / \mathrm{z} 557[\mathrm{M}-\mathrm{H}]^{-}$corresponding to hydroxyhirsuteine monoglucuronide in addition to a fragment ion peak at $\mathrm{m} / \mathrm{z} 381$ $[\mathrm{M}-\mathrm{H}-\mathrm{GlcUA}]^{-}$. The molecular formula, $\mathrm{C}_{28} \mathrm{H}_{33} \mathrm{~N}_{2} \mathrm{O}_{10}$, was determined based on the molecular ion peak observed on FAB-MS and by HR-FAB-MS measurement. Enzymatic hydrolysis of HT1 with $\beta$-glucuronidase gave a product that was identified as 11-hydroxyhirsuteine based on its retention time and UV spectrum during HPLC relative to HT2. ${ }^{1} \mathrm{H}-$ and ${ }^{13} \mathrm{C}$-NMR spectra were very similar to those of 11 -hydroxyhirsuteine, except for the $\beta$-glucuronic acid signal. On HMBC, long-range correlation was observed between $\mathrm{H}-1^{\prime}$ at $\delta 4.88$ and $\mathrm{C}-11$ at $\delta 152.7$. Therefore, HT1 was identified as 11-hydroxyhirsuteine-11- $O$ - $\beta$-D-glucuronide.

Metabolite HS1 was obtained as an amorphous powder, $[\alpha]+5.0^{\circ}$. FAB-MS showed a pseudomolecular ion peak at $\mathrm{m} / \mathrm{z} 559[\mathrm{M}-\mathrm{H}]^{-}$corresponding to hydroxyhirsutine monoglucuronide in addition to a fragment ion peak at $\mathrm{m} / \mathrm{z} 383$ $[\mathrm{M}-\mathrm{H}-\mathrm{GlcUA}]^{-}$. The molecular formula, $\mathrm{C}_{28} \mathrm{H}_{35} \mathrm{~N}_{2} \mathrm{O}_{10}$, was determined based on the molecular ion peak observed on FAB-MS and by HR-FAB-MS measurement. Enzymatic hydrolysis of HS1 with $\beta$-glucuronidase gave an aglycone, which was assumed to be 11-hydroxyhirsutine from its HPLC behavior. Furthermore, the NMR spectrum of HS1 was superimposable on that of 11-hydroxyhirsutine, except for the $\beta$-glucuronic acid signal. The location of the glucuronic acid moiety was confirmed by HMBC to be between the anomeric proton $\left(\mathrm{H}-1^{\prime}\right)$ at $\delta 4.91$ and $\mathrm{C}-11$ at $\delta 152.8$ for the 11-hydroxyhirsutine moiety. Accordingly, HS1 was identified as 11-hydroxyhirsutine-11- $O$ - $\beta$-D-glucuronide.

Metabolites HT3, HS3, HT4 and HS4 were confirmed to be HT, HS, 11-hydroxyhirsuteine-11- $O$ - $\beta$-D-glucuronide and 11-hydroxyhirsutine-11- $O-\beta$-D-glucuronide, respectively, based on direct comparison of spectroscopic data with authentic samples or HT1 and HS1 isolated from urine sample.

The chemical structures of these metabolites are shown in Fig. 3.

Quantification of Metabolites The urinary excretion profiles of metabolites after administration of $50 \mathrm{mg} / \mathrm{kg} \mathrm{HT}$ and HS are shown in Table 1. The cumulative amounts of metabolites (HT1-HT3 and HS1-HS3) excreted in urine within $72 \mathrm{~h}$ corresponded to $9.38 \pm 2.19 \%, 3.49 \pm 1.32 \%$ and $1.07 \pm 0.28 \%$ of HT dose administered, and $16.58 \pm 2.44 \%$, $8.73 \pm 1.85 \%$ and $0.66 \pm 0.19 \%$ of HS dose administered. The total cumulative mean was $13.94 \pm 3.79 \%$ and $25.97 \pm 4.48 \%$ of HT and HS doses administered, respectively. 
The biliary excretion of metabolites is shown in Table 2 . The total cumulative amounts of HT1 and HS1 excreted within $72 \mathrm{~h}$ corresponded to $35.02 \pm 1.29 \%$ and $45.62 \pm$ $5.35 \%$ (mean \pm S.E., $n=6$ ) of HT and HS doses administered, respectively.

Incubation of HT and HS HPLC analysis of the HT and HS solutions after incubation with rat liver microsomes revealed the presence of metabolites. These metabolites were identified as 11-hydroxy metabolites based on comparisons of retention time and UV spectral data with those of authentic samples. As shown in Fig. 4, the 11-hydroxylation activity
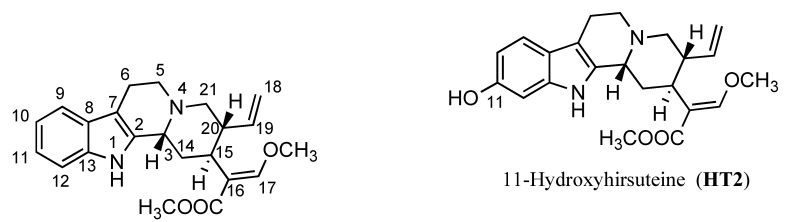

11-Hydroxyhirsuteine (HT2)

Hirsuteine (HT)

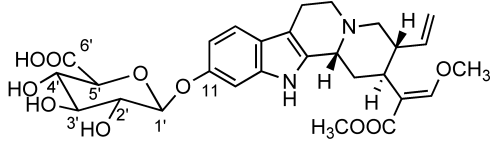

11-Hydroxyhirsuteine-11-O- $\beta$-D-glucuronide (HT1)
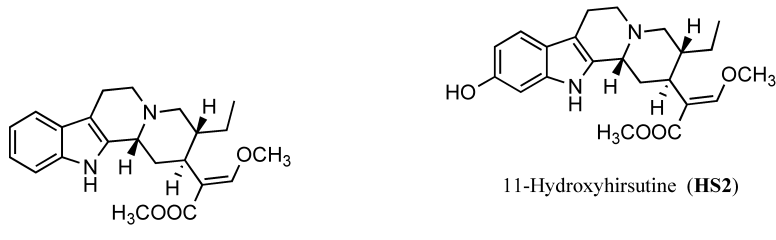

11-Hydroxyhirsutine (HS2)

Hirsutine (HS)

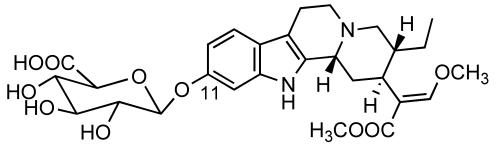

11-Hydroxyhirsutine-11-O- $\beta$-D-glucuronide (HS1)

Fig. 3. Structures of HT and HS Metabolites was found to increase with microsomal protein in a concentration-dependent manner, up to about $0.5 \mathrm{mg} / \mathrm{ml}$. Therefore, the inhibition study was performed at a protein concentration of $0.5 \mathrm{mg} / \mathrm{ml}$. The effects of nonselective and CYP2C inhibitors on the formation of 11-hydroxy metabolites are presented in Fig. 5. SKF-525A $(62.5-500 \mu \mathrm{M})$, a nonselective CYP inhibitor, inhibited the hepatic microsomal metabolism of HT and HS by $28-83 \%$ and $68-76 \%$, respectively. Cimetidine $(62.5-500 \mu \mathrm{M})$, a CYP2C inhibitor, also decreased the HT and HS 11-hydroxy formation by $31-65 \%$ and $18-63 \%$, when compared with inhibitor-free controls.

\section{DISCUSSION}

The hooks of Uncaria rhynchophylla, sinensis, and macrophylla are used in traditional Chinese herbal medicines as spasmolytic, analgesic and sedative treatments for various symptoms associated with hypertension and cerebrovascular disorders. ${ }^{1,2)} \mathrm{HT}$ and HS were isolated as major active indole alkaloids from the Uncaria species. ${ }^{7-9)}$ To date, however, no studies have been carried out to determine their metabolic fates. Therefore, we studied the metabolism and excretion of these active indole alkaloids in rats.

Using an HPLC system with a photodiode array detector, we confirmed that three metabolites (HT1-3 and HS1-3) were present in the urine of rats orally administered HT and HS. The chemical structures of these metabolites were determined to be 11-hydroxyhirsuteine-11- $O$ - $\beta$-D-glucuronide (HT1), 11-hydroxyhirsuteine (HT2), 11-hydroxyhirsutine-11$O$ - $\beta$-D-glucuronide (HS1), 11-hydroxyhirsutine (HS2) and the unchanged parent compounds HT (HT3) and HS (HS3) based on direct isolation in urine samples and spectroscopic data. On the other hand, the chromatograms of bile samples showed only the presence of a single metabolite (HT4 and HS4) each for HT and HS. The spectroscopic and chemical data of the metabolites were consistent with the urinary metabolites HT1 and HS1. Thus, after oral administration in rats, it appears that HT and HS undergo 11-hydroxylation of

Table 1. Urinary Excretion of the Metabolites in Rats following the Oral Administration of HT and HS (50 mg/kg)

\begin{tabular}{|c|c|c|c|c|c|}
\hline \multirow{2}{*}{$\begin{array}{c}\text { Parent } \\
\text { compounds }\end{array}$} & \multirow{2}{*}{ Metabolites } & \multicolumn{4}{|c|}{ Metabolites $\%$ of dose } \\
\hline & & $0-24 \mathrm{~h}$ & $24-48 \mathrm{~h}$ & $48-72 \mathrm{~h}$ & Total \\
\hline \multirow[t]{4}{*}{ HT } & HT1 & $6.21 \pm 1.14$ & $1.88 \pm 0.48$ & $1.29 \pm 0.57$ & $9.38 \pm 2.19$ \\
\hline & HT2 & $1.67 \pm 0.29$ & $1.22 \pm 0.72$ & $0.60 \pm 0.31$ & $3.49 \pm 1.32$ \\
\hline & HT3 & $1.06 \pm 0.28$ & $0.01 \pm 0.00$ & N.D. & $1.07 \pm 0.28$ \\
\hline & Total & $8.94 \pm 1.71$ & $3.11 \pm 1.20$ & $1.89 \pm 0.88$ & $13.94 \pm 3.79$ \\
\hline \multirow[t]{4}{*}{ HS } & HS1 & $10.61 \pm 0.75$ & $4.39 \pm 1.40$ & $1.58 \pm 0.29$ & $16.58 \pm 2.44$ \\
\hline & HS2 & $5.85 \pm 1.05$ & $2.13 \pm 0.53$ & $0.75 \pm 0.27$ & $8.73 \pm 1.85$ \\
\hline & HS3 & $0.66 \pm 0.19$ & N.D. & N.D. & $0.66 \pm 0.19$ \\
\hline & Total & $17.12 \pm 1.99$ & $6.52 \pm 1.93$ & $2.33 \pm 0.56$ & $25.97 \pm 4.48$ \\
\hline
\end{tabular}

Data expressed as means \pm S.E.M. $(n=6)$

Table 2. Biliary Excretion of Metabolites in Rats Following Oral Administration of HT and HS (50 mg/kg)

\begin{tabular}{|c|c|c|c|c|c|}
\hline \multirow{2}{*}{$\begin{array}{c}\text { Parent } \\
\text { compounds }\end{array}$} & \multirow{2}{*}{ Metabolites } & \multicolumn{4}{|c|}{ Metabolites $\%$ of dose } \\
\hline & & $0-24 \mathrm{~h}$ & $24-48 \mathrm{~h}$ & $48-72 \mathrm{~h}$ & Total \\
\hline HT & HS4 & $33.71 \pm 0.76$ & $1.31 \pm 0.53$ & N.D. & $35.02 \pm 1.29$ \\
\hline HS & HS4 & $42.71 \pm 3.70$ & $2.76 \pm 1.54$ & $0.15 \pm 0.11$ & $45.62 \pm 5.35$ \\
\hline
\end{tabular}

Data expressed as means \pm S.E.M. $(n=6)$ 


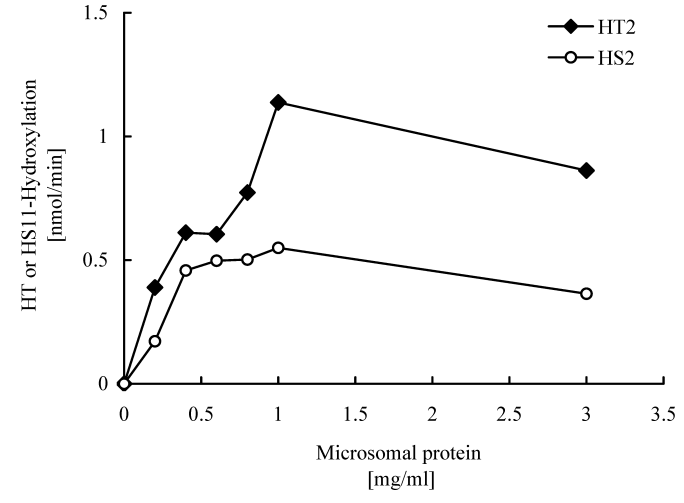

Fig. 4. Dependence of Protein Concentrations on HT and HS 11-Hydroxylation Catalyzed by Rat Liver Microsomes

(a)

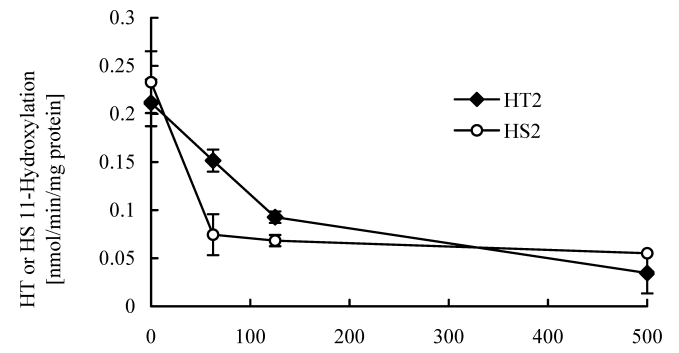

SKF525A $[\mu \mathrm{M}]$

(b)

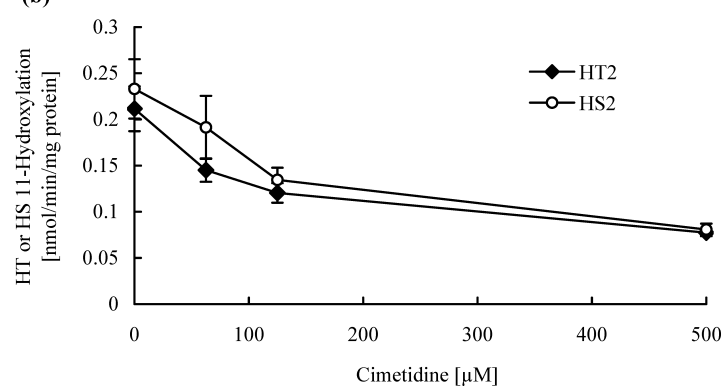

Fig. 5. The Effects of CYP Inhibitors, SKF525A (a) and Cimetidine (b) on HT and HS 11-Hydroxylation Catalyzed by Rat Liver Microsomes

the aromatic ring followed by conjugation; in other words, the metabolism of HT and HS in rats focuses on C-11 in the aromatic ring.

Quantitative analysis demonstrated that the urinary excretion of HT and HS was terminated within $24 \mathrm{~h}$ of oral administration, while the metabolites were excreted for up to $72 \mathrm{~h}$. The total cumulative amounts of the metabolites and unchanged HT and HS in the urine were approximately 14 and $26 \%$ of the doses, respectively, and the unchanged forms accounted for only $1 \%$. On the other hand, the total cumulative biliary excretion of HT and HS glucuronides was 35 and $46 \%$, respectively, and most of this excretion occurred within $24 \mathrm{~h}$. These results suggest that orally administered HT and HS are predominantly metabolized to the corresponding 11hydroxy forms, followed by $\beta$-glucuronidation, and that the oral bioavailabilities of HT or HS, per se, are relatively low. Further detailed study of plasma concentrations of HT and HS is required to clarify this notion. Orally administered phenolic compounds, particularly those with low polarity, undergo glucuronide and sulfate conjugation in the intestinal mucosa, the liver and other tissues. We previously reported that paeonol (2-hydroxy-4-methoxyacetophenone) orally administered to rats was excreted in the bile and urine as four sulfated metabolites. ${ }^{18)}$ However, in the present study, we were unable to detect sulfates in the bile and urine after HT and HS administration. Based on these results, we speculate that both alkaloids are high-affinity substrates for glucuronidation rather than sulfation, and that the high molecular weight and high polarity of the glucuronides promote the excretion of the alkaloids in bile. This would result in the long-term accumulation of both alkaloid metabolites in the body.

The present study clearly showed that rat liver microsome enzymes catalyzed the mono-hydroxylation of HT and HS. Hydroxylation (phase-1 metabolism) is catalyzed by liver microsome enzymes such as CYP1A, 2C, 2B, and 2D in rat. Among these, the CYP2C family is the major isoforms in rats $^{19,20)}$ and efficiently catalyzes the 7-hydroxy formation of warfarin. $^{21)}$ Thus, we used chemical CYP inhibitors, SKF 525A and cimetidine, to identify whether the CYP2C family is related to the HT and HS hydroxylation. As expected, the addition of cimetidine, as well as SKF 525A, decreased the 11-hydroxy formation of HT and HS, which suggests that CYP2C enzymes are involved, at least in part, in the specific 11-hydroxylation of HT and HS.

Le Verge et al. reported that yohimbine, which contains a tetracyclic indole alkaloid skeleton similar to those of HT and HS, is metabolized to 10- and 11-monohydroxy forms in humans. ${ }^{22)}$ The 11-hydroxyyohimbine, but not 10-hydroxy, possesses the same $\alpha_{2}$-adrenoceptor blocking activity as yohimbine. $^{23)}$ Furthermore, the 11-hydroxyyohimbine is highly present in plasma and exhibits a longer elimination half-life than the parent drug $(6 \mathrm{~h} v s .1 \mathrm{~h}){ }^{22)}$ Ozaki reported that HT and HS have hypothermic effects in mice (30 or $60 \mathrm{mg} / \mathrm{kg}$, i.p.); however, these alkaloids exhibit prolonged hypothermic effects when compared with aminopyrine, the positive control. ${ }^{8)}$ Although HT and HS possess a central depressive and vasodilative effect in addition to hypothermia induction activity, the involvement of 11-hydroxymetabolites in these activities cannot be excluded. Further work is necessary to determine whether hydroxy metabolites are involved in the pharmacological effects of HT, HS.

\section{CONCLUSION}

In this investigation, two mono-hydroxylated phase-1 metabolites of HT and HS were isolated and identified as 11hydroxyindoles based on spectroscopic data. To our knowledge, these are the first data relating to the metabolism of HT and HS in vivo and in vitro. The present results will facilitate an improved understanding of pharmacokinetics and pharmacodynamics of HT and HS.

\section{REFERENCES}

1) Yano S., J. Traditional Sino-Japanese Medicine, 8, 47-52 (1987).

2) Hsieh C. L., Chen M. F., Li T. C., Li S. C., Tang N. Y., Hsieh C. T., Pon C. Z., Lin J. G., Am. J. Chin. Med., 27, 257-264 (1999).

3) Haginiwa J., Sakai S., Aimi N., Yamanaka E., Shinma N., Yakugaku Zasshi, 93, 448-452 (1973).

4) Aimi N., Yamanaka E., Shinma N., Fujiu M., Kurita J., Sakai S., 
Haginiwa J., Chem. Pharm. Bill., 25, 2067-2071 (1977).

5) Lee J. S., Yang M. Y., Yeo H., Kim J., Lee H. S., Ahn J. S., Bioorg. Med. Chem. Lett., 17, 1492-1432 (1999).

6) Shimada Y., Goto H., Kogure T., Shibahara N., Sakakibara I., Sasaki H., Terasawa K., Am. J. Chin. Med., 29, 173-180 (2001).

7) Ozaki Y., Nippon Yakurigaku Zasshi, 94, 17-26 (1989).

8) Ozaki Y., Nippon Yakurigaku Zasshi, 95, 47-54 (1990).

9) Shimada Y., Goto H., Itoh T., Sakakibara I., Kubo M., Sasaki H., Terasawa K., J. Pharm. Pharmacol., 51, 715-722 (1999).

10) Abdel-Hafez A. A., Meselhy M. R., Nakamura N., Hattori M., Watanabe H., Mohamed T. A., Mahfouz N. M., el-Gendy M. A., Chem. Pharm. Bull., 46, 1486-1487 (1998).

11) The 125th Annul Meeting of Pharmaceutical Society of Japan, Tokyo, May 2005.

12) Sakakibara I., Terabayashi S., Kubo M., Higuchi M., Komatsu Y., Okada M., Taki K., Kamei J., Phytomedicine, 6, 163-168 (1999).

13) Daniel W. A., Syrek M., Haduch A., Eur. Neuropsychopharmacol., 12, $371-377$ (2002)

14) Easterbrook J., Fackett D., Li A. P., Chem. Biol. Interact., 134, 243-
249 (2001).

15) Trager W. F., Lee C. M., Phillipson J. D., Beckett A. H., Tetrahedron, 23, 1043-1047 (1967).

16) Ohhira S., Watanabe M., Matusi H., Toxicol. Lett., 148, 141-148 (2004).

17) Levine M., Law E. Y., Bandiera S. M., Chang T. K., Bellward G. D., J. Pharmacol. Exp. Ther., 284, 493-499 (1998).

18) Yasuda T., Kon R., Nakazawa T., Ohsawa K., J. Nat. Prod., 62, 11421144 (1999).

19) Cheng K. C., Schenkman J. B., J. Biol. Chem., 257, 2378-2385 (1982).

20) Mimura M., Yamazaki H., Sugahara C., Hiroi T., Funae Y., Shimada T., Biochem. Pharmacol., 47, 1957-1963 (1994).

21) Murray M., Reidy G. F., Pharmacol. Rev., 42, 85-101 (1990).

22) Le Verge R., Le Corre P., Chevanne F., Döe De Maindreville M., Royer D., Levy J., J. Chromatogr., 14, 283-292 (1992).

23) Berlan M., Le Verge R., Galitzky J., Le Corre P., Br. J. Pharmacol., 108, 927-932 (1993). 